\title{
A detailed image of the continent-borderland transition beneath Long Beach, California
}

\author{
Robert W. Clayton ${ }^{\oplus}$ \\ California Institute of Technology, Pasadena, CA 91125,USA.E-mail: clay@gps.caltech.edu
}

Accepted 2020 June 8. Received 2020 June 8; in original form 2020 March 6

\begin{abstract}
SUMMAR Y
New crustal images beneath Long Beach, California show the region of the Inner Borderland to continent transition. The cross-sections are obtained from stacked autocorrelations of virtual sources generated from oil-industry data recorded in the city of Long Beach, CA. They show that the Moho is dipping at $65^{\circ}$ and obliquely truncates an $\sim 10 \mathrm{~km}$ thick flat-lying lower crustal fabric. The Moho appears to be fault controlled and an integral part of the extrusion of the Catalina Schist that underlays the Inner Borderland. The basement interface has significant offsets of up to $2 \mathrm{~km}$, none of which correspond to the mapped trace of the Newport-Inglewood Fault.
\end{abstract}

Key words: Crustal imaging; Seismic interferometry; Seismic noise.

\section{INTRODUCTION}

The Inner Borderland is generally defined as the offshore region of southern California approximately between Catalina Island and the shoreline (see Fig. 1). It was created in the Miocene as part of the extension that accompanied the rotation of the Transverse Ranges from a position that was parallel to the Pacific plate motion to one that is nearly perpendicular to it (Luyendyk 1991; Nicholson et al. 1994; Atwater and Stock 1998). In this process, the region was stretched by almost $200 \mathrm{~km}$ (Couch and Suppe 1993), leaving a present crustal thickness of approximately $20 \mathrm{~km}$. It is composed primarily of medium- to high-grade metamorphic rocks known as Catalina Schist, which are thought to be a remnant of the previous subduction environment (Crouch and Suppe 1993). This stretching process also formed the onshore basins in the Los Angeles area on the adjacent onshore region (Wright 1991).

The formation of the Inner Borderland is commonly thought to be a core complex that emerged due to a slab window created at the time of subduction cessation (Couch and Suppe 1993). The pathway to exhume the schist is described as a detachment-like fault that extends under the Los Angles Basin. Recently, Chapman et al. (2010) and Chapman (2017) have suggested that the schists that are exposed in S. California were formed by extrusion along high-angle faults as a result of a shallow subduction process. The Rand and related schists were exposed as a result of the subduction system that ingested the Shatsky-Hess Rise $90 \mathrm{Ma}$ (Saleeby 2003). This mechanism could also explain the extraction of the Catalina Schist, which was extruded in the Miocene as part of the extension of the Los Angeles Basin and the Inner Borderland. In this study, we image the continent-Inner Borderland transition to look for this pathway.

Long Beach, CA is situated above the transition from Inner Borderland to continent where the crust changes from $20 \mathrm{~km}$ (ten Brink et al. 2000) to approximately $24 \mathrm{~km}$ thick (Ma and Clayton 2016). This transition occurs over a distance of $10 \mathrm{~km}$, which means the average dip of the Moho is approximately $22^{\circ}$. The 1994 onshoreoffshore Los Angeles Region Seismic Experiment (LARSE) seismic survey gave an indication of this dip, but could not locate it accurately (Godfrey et al. 2002; Nazareth and Clayton 2003). There have been regional-scale models (Richards-Dinger and Shearer 1997; Zhou et al. 2010) that cross through the Long Beach area, but they lack the resolution to reveal the structure presented here. The Southern California Earthquake Center (SCEC) has developed two velocity models - CVM-H15 (Shaw et al. 2015) and CVM-S4.26 (Lee et al. 2014) - but these also do not have the structural detail presented here. In another study, Schmandt and Clayton (2013) determined that the Moho dip was locally as steep as $65^{\circ}$ based on teleseismic waves recorded by the same oil-industry array that will be used in this study.

In this paper, a new method of subsurface imaging is applied to dense oil-industry arrays. It confirms that the Moho dip is locally as steep as $65^{\circ}$, but also shows that this interface is a truncational discontinuity that may have provided a pathway for the emergence of the Catalina Schist and the formation of the Inner Borderland core complex. The image also shows the laminar nature of the lower crust.

\section{DATA AND METHOD}

The results presented in this paper are based on a 3-D seismic reflection surveys done by Nodal Seismic in 2011 and 2012, for Signal Hill Petroleum. The survey area is shown in Fig. 1 and spans a $10 \mathrm{~km} \times 10 \mathrm{~km}$ area adjacent to the coast. The data were acquired with autonomous sensors ('nodes') that recorded 24-hr a day for time spans of 3-6 months. The nodes have a vertical-component 


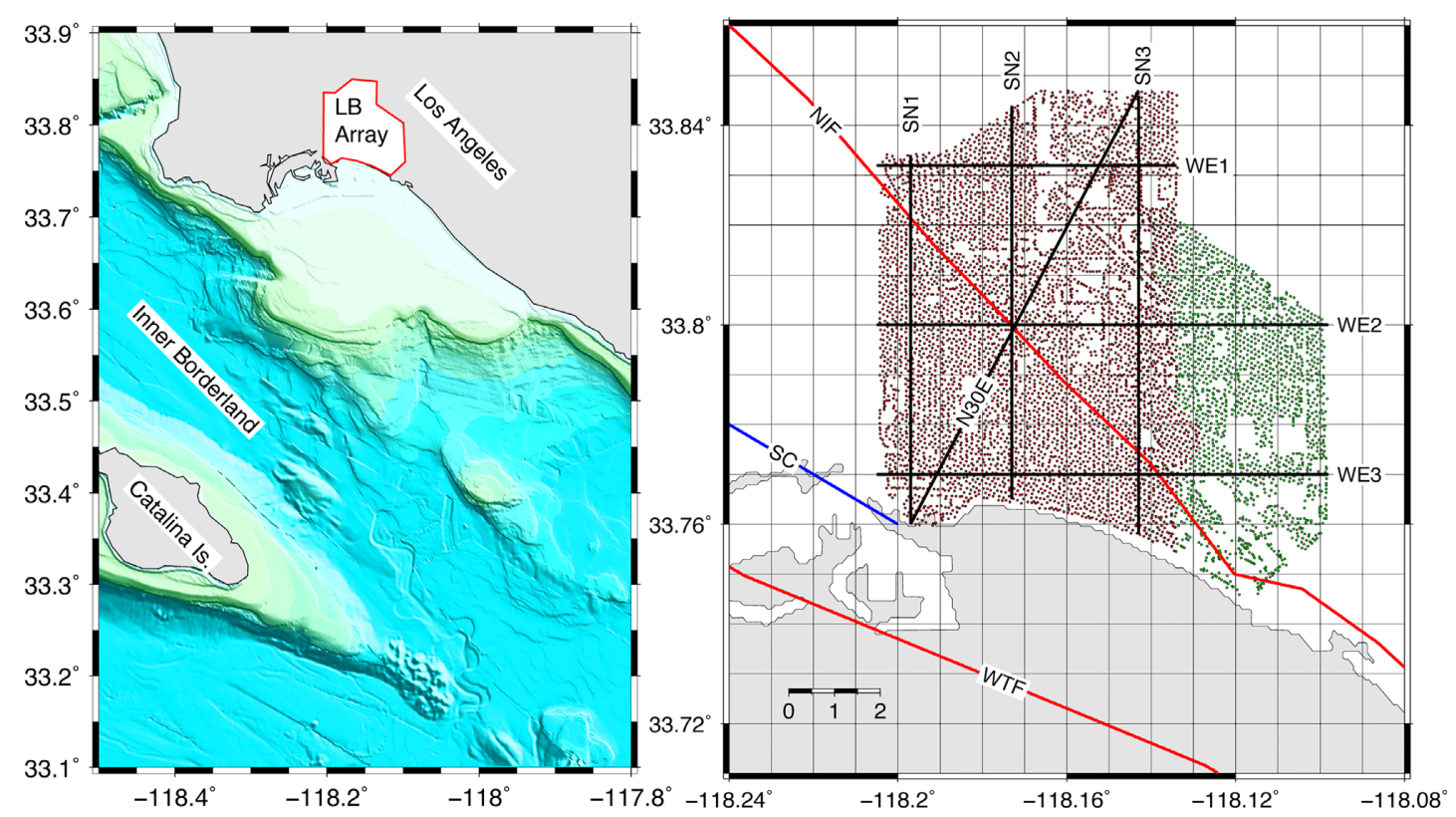

Figure 1. Map of Long Beach arrays. The left-hand panel shows the location of the arrays in the greater Los Angeles area. The right-hand panel shows the details of the 2011 (red dots) and 2012 (green dots) industry arrays in Long Beach, CA. There are approximately 7500 receiver position with an average spacing of $100 \mathrm{~m}$. The Newport-Inglewood Fault (NIF) and the Wilmington Thrust Fault (WTR) are indicated with red lines, and the position of the steep Moho gradient reported by Schmandt and Clayton (2013) is marked with the blue line (SC). The labelled black lines are the location of cross-section shown in following figures.

geophone that has a low-frequency corner at $10 \mathrm{~Hz}$. Previous studies have shown that they are sensitive to motions down to $0.1 \mathrm{~Hz}$. The raw data are sampled at 500 samples per second (sps). These data were then cross-correlated with each other to produce a set of 7500 virtual source gathers (Lin et al. 2013a), which have been used in a surface wave analysis to determine the shallow 3-D shear-wave velocities (Lin et al. 2013a), and in a refracted $P$-wave analysis to determine the compressional velocities to a depth of $2 \mathrm{~km}$ (Nakata et al. 2015; Castellanos et al. 2020).

In this paper, we will use a technique described in Clayton (2020), to stack short-offset correlations together to produce a zero-offset reflection section. The stack involves summing together 40-50 correlation traces for each output trace, so the signal-to-noise ratio is considerably improved by this process. The images are then enhanced by removing the average of the stacked traces from the data volume, which produces an estimate of the reflectivity. This step is similar to the deconvolution process used in single-component receiver functions (Langston and Hammer 2001; Ruigrok and Wapenaar 2012; Schmandt and Clayton 2013).

The effective energy source for this image is the microseismic energy produced by ocean waves in the adjacent offshore region (Lin et al. 2013a) and possibly by the coda of large earthquakes that occurred during the survey (Lin et al. 2013b). Energy contributions from the active sources used during the survey (vibrator trucks) and the anthropological noise are negligible (Lin et al. 2013a), due to the depth of the imaging targets and the frequency bandwidth of this study. The effective bandwidth of the source-eceiver combination is approximately $0.2-3 \mathrm{~Hz}$, which is considerably lower than a conventional industry seismic survey, but is sufficient to image the mid-and lower crust where traditional reflection methods have difficulty with energy penetration.

The subsurface image produced by the above processing is a zero-offset section and as such contains no velocity information. Consequently an accurate time to depth conversion cannot be done with these images. Instead, we use a constant crustal velocity of $6 \mathrm{~km} \mathrm{~s}^{-1}$ to provide an approximate depth scale that can be simply converted with alternative velocity models. This is the approximate average crustal velocity of the SCEC velocity models in this region (Lee et al. 2014; Shaw et al. 2015), which differ significantly from each other in the Long Beach area. Since neither of these models contains the structural detail of the images presented here, there is no justification to be more precise than this.

\section{RESULTS}

An example of the resulting images is presented in Fig. 2. This is an N-S cross-section (line NS-1 in Fig. 1) that shows a few near horizontal interfaces in the upper crust, one of which is interpreted to be the basin-sediment interface (basement) based on its approximate depth of 3-4 km (Wright 1991). There are apparent offsets of 0.5 and $2 \mathrm{~km}$ in the upper crust layers that may indicate faulting (yellow vertical lines in B), but none correspond to the surface location of the Newport-Inglewood Fault, or any other established fault in the area.

Deeper in the section is a set of nearly horizontal laminar-like structures that are interpreted as the lower crust based on their depth interval and structural expression. Several authors have used laminar structures created by various mechanisms as a model of the lower crust (Klemperer 1987; Wenzel et al. 1987; Holbrook et al. 1991). The most compelling model for this location is volcanic sill-like intrusions possibly with a horizontal tectonic stretch imparted during large magnitude extension of the core complex. This contrasts with the single sill intrusion imaged by Wrona et al. (2019) in the North Sea. The stretched region resulting from the rotation of the Transverse Ranges underwent extensive volcanism in the middle-Miocene as evidenced by volcanic centres along the 

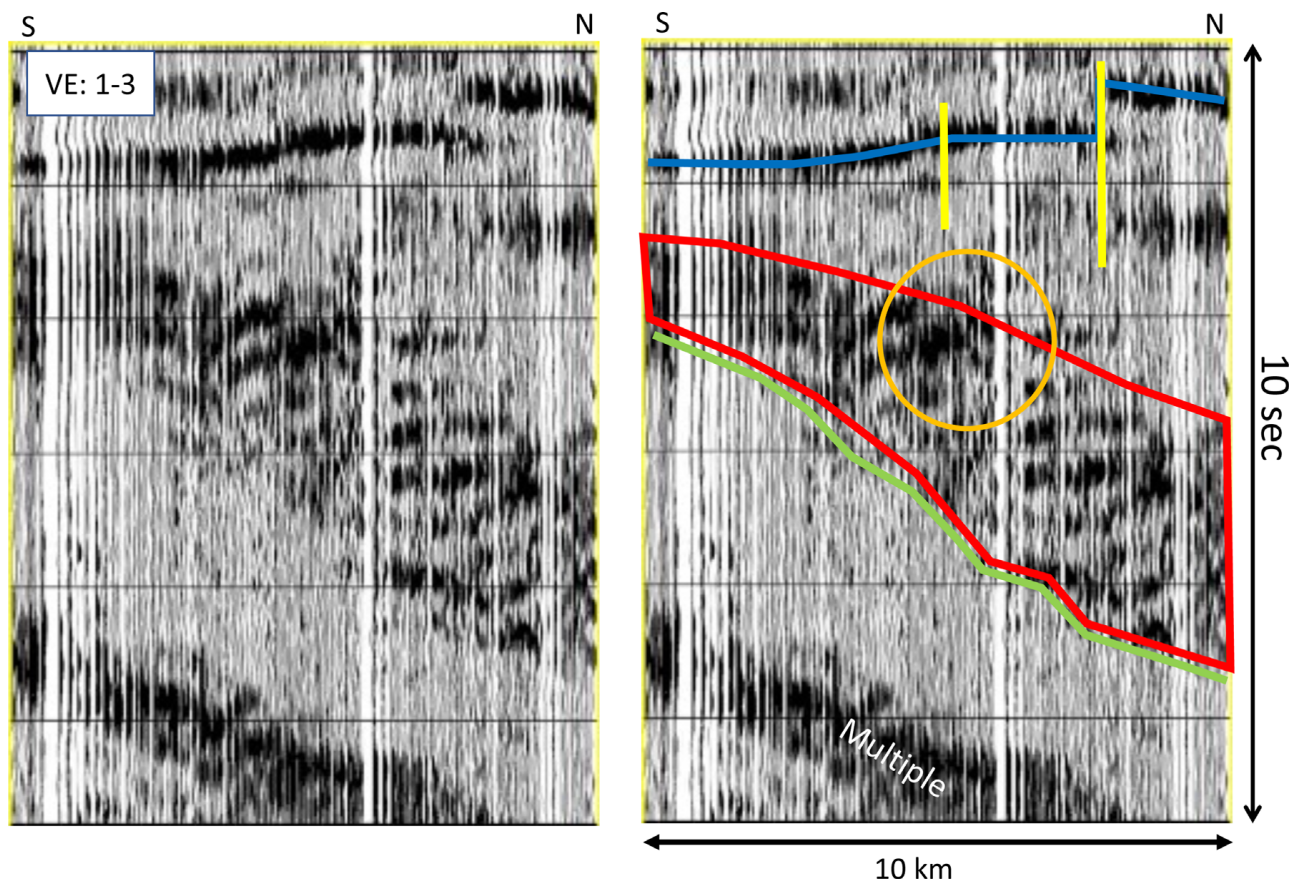

Figure 2. Cross-section along NS1. The left-hand panel shows the autocorrelation section. The vertical axis is $10 \mathrm{~s}$. The timing lines are every $5 \mathrm{~km}$, assuming a velocity of $6 \mathrm{~km} \mathrm{~s}^{-1}$. The right-hand panel has the interpretation superimposed. The blue interface is basement and offsets marked in yellow. The red polygon denotes the lower crust, which is characterized by multiple lamina. The green denotes end of the laminar zone and is interpreted as the Moho. The orange circle is an example of deformation in the lower crust.

outer edge of the Inner Borderland (Legg et al. 2004). These images indicate $10 \mathrm{~km}$ of underplating occurred during the extension. The laminae are laterally continuous over a $2-3 \mathrm{~km}$ scale and have a thickness of approximately $2 \mathrm{~km}$. There are zones of superposed deformation (see the orange circle in Fig. 2) that indicate that there was some tectonic deformation post-emplacement (Legg et al. 2004).

The images also show that the lamina appear to truncate along an unseen dipping boundary (the green line in Fig. 2), which we interpret as the Moho. The reason that there is no direct image of this interface is that with an apparent dip of $45^{\circ}$, the specular Moho reflection would only appear beyond the northern edge of the seismic array. The Moho is however seen in the study by Schmandt and Clayton (2013), which will be discussed later. Truncation of the lower crustal lamina along the steeply dipping Moho segment could arise from a large normal fault that produced the steeply dipping segment, or by necking that both truncated the lamina and accentuated it by a horizontal stretch.

In Fig. 3, a number of N-S and E-W cross-sections through the data volume are shown. The two additional N-S sections show that the Moho continues to be imaged as truncated edge of the lower crustal lamina with an average apparent dip of $45^{\circ}$. There are some variations indicating more localized tectonic overprints. The E-W cross-sections show that there is an eastward apparent dip component to the Moho of $\sim 25^{\circ}$. Taking the apparent $\mathrm{N}$ dip of $45^{\circ}$ and the apparent $\mathrm{E}$ dip of $25^{\circ}$, results in a true dip of the Moho that is $65^{\circ}$ along a N30E line (shown in Fig. 1, Tanner 1956). The dips calculated above are done on an unmigrated section, but should be correct since they are based on approximately horizontal lamina. The middle Miocene relative plate motion vector was approximately N60W, which is parallel to the strike of the Moho.
In a study using one-component receiver functions from teleseismic earthquakes, Schmandt and Clayton (2013) determined that the Moho in this area dipped at $65^{\circ}$ along a backazimuth line of S30W (i.e. in agreement with the $\mathrm{N} 30 \mathrm{E}$ line above). This agreement lends support for the interpretation that the Moho is the interface that the laminae are truncated against in the cross-sections. In Fig. 4, the picked interfaces shown in Fig. 3 are shown as a 3-D projection. They show the structure described above as simple interfaces representing the basement, upper/lower crust boundary and the Moho. Additional displays of these surfaces are available in the Supporting Information, along with the digital values. The true-dip crosssection is also shown in Fig. 4, where it is placed in its tectonic setting.

Also shown in Fig. 3 is the seismicity along the cross-sections. The earthquake locations are from Hauksson et al. (2012) and are for a 30-yr time span starting in 1981. The earthquakes are projected onto the cross-section lines from as far as $\pm 1 \mathrm{~km}$ from the line. The events span a magnitude range of 1.0-3.7 and the location accuracy is reported to be $\pm 1 \mathrm{~km}$. The seismicity shows no apparent relationship to the structural elements discussed above, but they are generally associated with reflectivity in the cross-sections. The events are not confined to the upper crust in agreement with Inbal et al. (2016), and they to do not align with the offsets observed in the basement indicating that these structures are likely inactive (at least in the 30-yr span of the catalogue).

\section{DISCUSSION}

The results show the structure in the transition between the Inner Borderland and the continent in the zone that underwent largescale extension in the Miocene during the rotation of the Transverse 


\section{$S$}
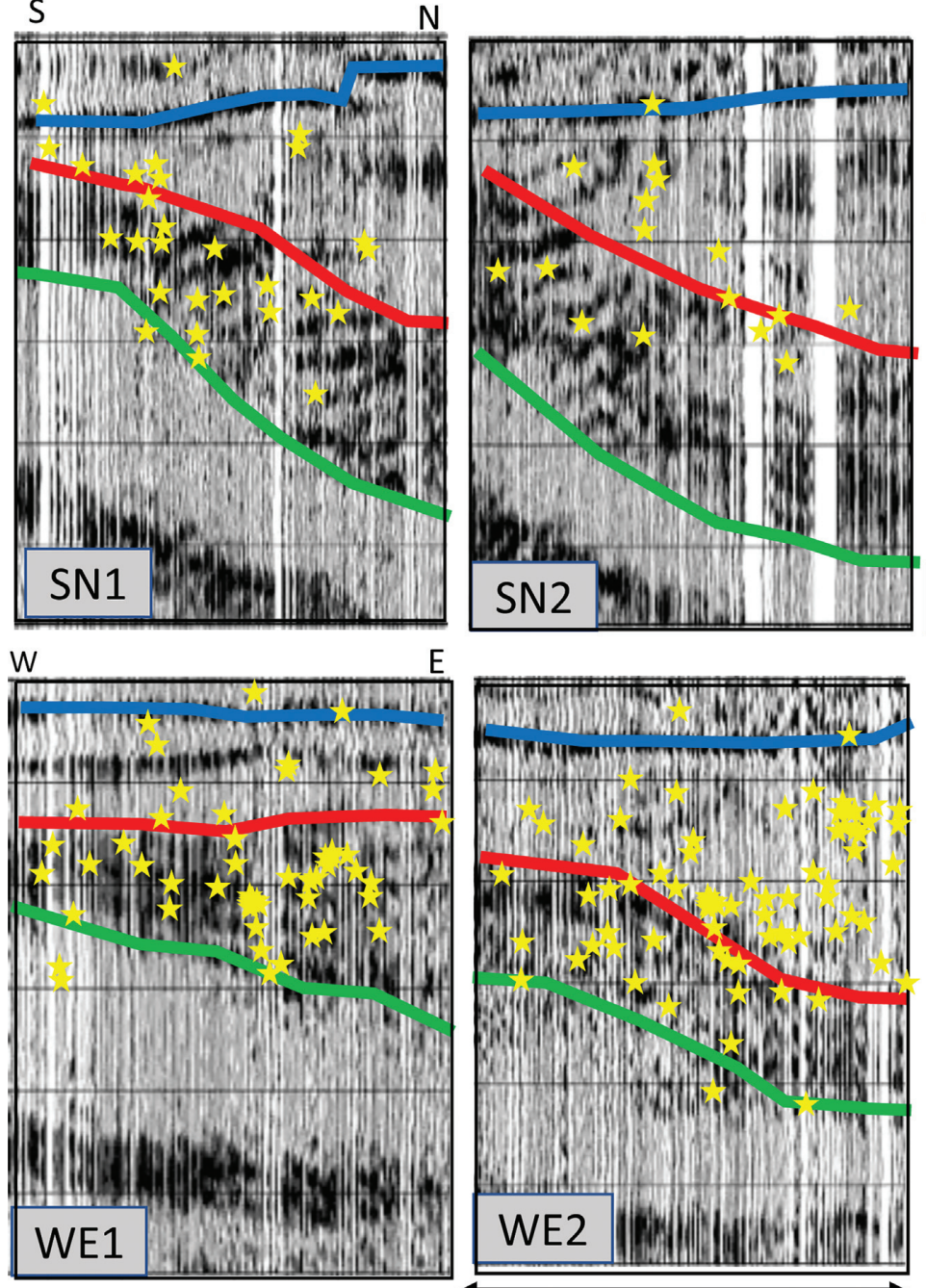

E

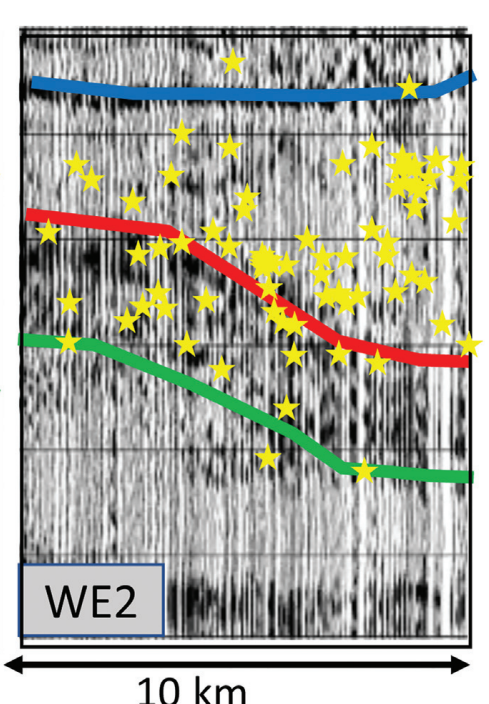

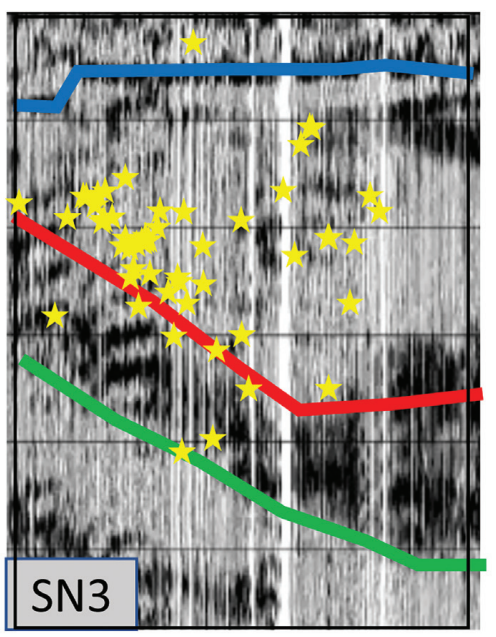

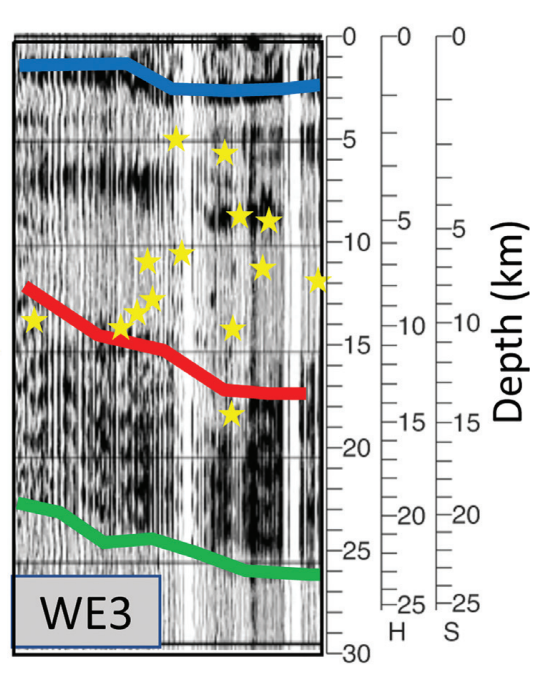

Figure 3. Cross-sections beneath Long Beach. The top row are NS lines and show the $45^{\circ}$ dipping lower crust and Moho. The bottom row is WE cross-sections and show an apparent dip of the Moho $25^{\circ}$ in EW direction. The blue, red and green lines mark the basement, top of lower crust and Moho, respectively. The yellow stars are earthquakes within $1 \mathrm{~km}$ of the line. The three depth scale on the lower right are for: a constant velocity of $6 \mathrm{~km} \mathrm{~s}{ }^{-1}$, the SCEC-H15 velocity model $(\mathrm{H})$ and the SCEC-S4.26 velocity model (S).

Ranges (Nicholson et al. 1994). Some of the resolved features have some bearing on the extension process itself. The laminar texture of the lower crust indicates the volcanism was a significant component of the extension and likely starts at the time of formation of the Inner Borderland as the near surface expressions of this volcanism are on the outer edges of the Inner Borderland (Legg et al. 2004). The steeply dipping segment of the Moho that is imaged in this study is most readily interpreted as a large normal fault offset in the Moho that was related to the extraction of the schist from the lower crust, and which now forms the regionally denuded lower plate of the Inner Borderland core complex. The process may be similar to that described by Chapman et al. (2017) in which the schist is transported from the prior subduction interface along a high-angle fault inland from the trench. In the Long Beach case, this fault would be the steeply dipping segment of the Moho that has been imaged. The Wilmington blind thrust fault (see Fig. 1) recently reported by Wolfe et al. (2019) may be the shallow component of this fault. The fault imaged here would need to become steeper toward the surface to spatially match the Wilmington Thrust Fault (WFT), as is the case with most faults in this area.

The surprising aspect of the section is how deep the energy penetrates. Reflectors can be seen down to at least the Moho. Only reflection surveys with very large sources have had success at imaging to this depth, and such large sources are not feasible in the highly urbanized area of the Long Beach survey.

\section{CONCLUSIONS}

The results presented here confirm the steep Moho gradient at the continent to Inner-Borderland transition in the Long Beach area, as reported by Schmandt and Clayton (2013). The Moho dips at $65^{\circ}$ over a horizontal distance of $10 \mathrm{~km}$ along a true dip line oriented N30E. The image shows the lower crust (zone of reflectivity) varies in thickness from 4 to $10 \mathrm{~km}$, and is composed of horizontal laminae that are $2 \mathrm{~km}$ thick and have a horizontal scale length of $2-3 \mathrm{~km}$. The laminae are mildly contorted in localized regions 

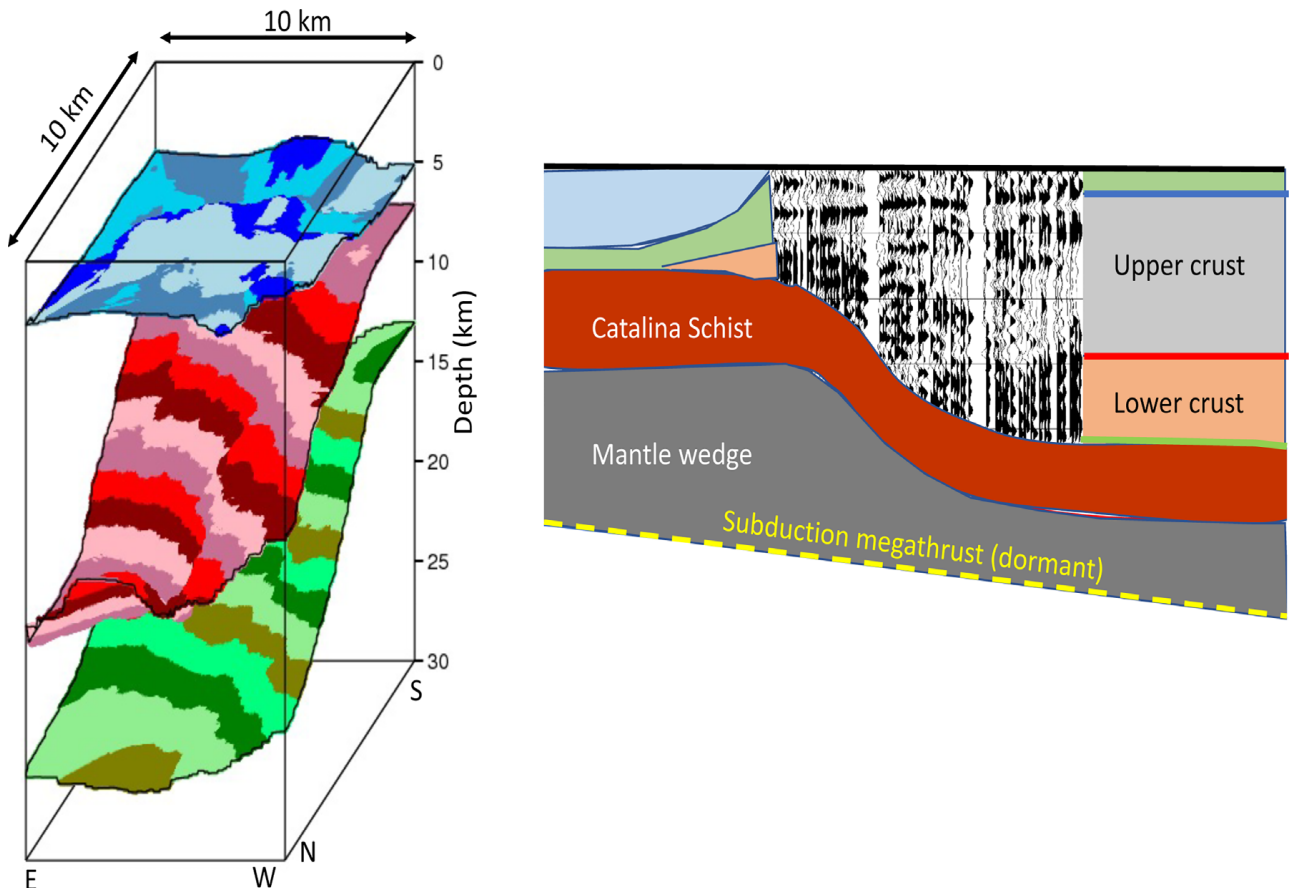

Figure 4. 3-D view of interfaces and true dip line. The left-hand panel shows the basement (blue), top of lower crust (red) and Moho (green) interfaces. The right-hand panel shows the true dip line along N30E embedded in a tectonic interpretation.

but are generally horizontal. The basement reflector is seen across the region at approximately 3-4 km depth and has apparent offsets of $0.5-2 \mathrm{~km}$, none of which are coincident with the NewportInglewood Fault. The seismicity in the area of the survey occurs in both the upper and lower crust, and appears to occur in areas of reflectivity.

\section{ACKNOWLEDGEMENTS}

The work was support under the NSF award EAR-1520081 and a THOR (Caltech internal research fund) award. We thank Signal Hill Petroleum for permission to use the Long Beach array data and Dan Hollis and Nodal Seismic for facilitating the interaction. This study benefitted from discussions with Mark Legg and Jason Saleeby. We also thank John Shaw and an anonymous reviewer for constructive comments that improved this paper. Data used in this study is the property of Signal Hill Petroleum and a "nondistribution' agreement with them is required from them to use data.

\section{REFER E N CES}

Atwater, T. \& Stock, J., 1998. Pacific-North America plate tectonics of the Neogene southwestern United States: an update, Int. Geol. Rev., 40, 375-402.

Castellanos, J., Clayton, R. \& Juarez, A., 2020. Using a time-based subarray method to extract and invert noise-derived body waves at Long Beach, California, J. geophys. Res.: Solid Earth, 125, e2019JB018855, doi:10.1029/2019JB018855.

Clayton, R., 2020. Imaging the subsurface with ambient noise autocorrelations, Seismol. Res. Lett., 91, 930-935.

Chapman, A., Kidder, S., Saleeby, J. \& Ducea, M., 2010. Role of extrusion of the Rand and Sierra da Salinas schists in the Late Cretaceous extension and the rotation of southern Sierra Nevada and vicinity, Tectonics, 29, TC5006, 21 pp., doi:10.1029/2009TC002597.
Chapman, A., 2017. The Pelona-Orocopia-Rand and related schists of southern California: a review of the best-known archive of shallow subduction on the planet, Int. Geol. Rev., 59(5-6), 664-701.

Couch, J. \& Suppe, J., 1993. Late Cenozoic tectonic evolution of the Los Angeles basin and inner California borderland: A model for core-complexlike crustal extension, Bull. geol. Soc. Am., 105, 1415-1434.

Godfrey, N., Fuis, G., Langenhiem, V., Okaya, D. \& Brocher, T., (2002), Lower crustal deformation beneath the central Transverse Ranges, southern California: results from the Los Angeles region seismic experiment, J. geophys. Res, 107, ETG 8-1-22, doi:10.1029/2001JB000354.

Hauksson, E., Yang, W. \& Shearer, P., 2012. Waveform relocation calatlog for southern California (1981 to 2011), Bull. seism. Soc. Am., 5, 2239 2244.

Holbrook, S., Catchings, R. \& Jarchow, C., 1991. Origin of deep crustal reflections: implications of coincident seismic refraction and reflection data in Nevada, Geology, 19, 175-179.

Inbal, A., Ampuero, J.-.P. \& Clayton, R., 2016. Localized seismic deformation in the upper mantle revealed by Dense Arrays, Science, 354, 88-92.

Klemperer, S., 1987. A relationship between continental heat flow and the seismic reflectivity of the lower crust, J. geophys, 61, 1-11.

Langston, C. \& Hammer, J., 2001. Vertical commponent P-wave receiver functions, Bulletin of the Seismological Society of America, 91, 6:18051819. doi: $10.1785 / 012000225$.

Lee, E., Chen, P., Jordan, T., Maechling, P., Denolle, M. \& Beroza, G., 2014. Full 3-D tomography structure in Southern California based on the scattering-integral and the adjoint-wavefield methods, J. geophys. Res, 119, 6421-6451.

Legg, M., Nicholson, C., Goldfinger, C., Milstein, R. \& Kamerling, M., 2004. Large enigmatic crater structure offshore southern California, Geophys. J. Int., 159, 803-815.

Lin, Fan-Chi, Li, D., Clayton, R. \& Hollis, D., 2013a. High-resolution shallow crustal structure in Long Beach, California: application of ambient noise tomography on a dense seismic array, Geophysics, 78(4), Q45-Q56.

Lin, F-C., Tsai, V., Schmandt, B., Duputel, Z. \& Zhan, Z., 2013b. Extracting seismic core phses with array interferometry, Geophys. Res. Lett., 40, 1049-1053. 
Luyendyk, B., 1991. A model for Neogene cristal rotations, transtension and transpression in southern California, Bull. geol. Soc. Am., 103, 15281536.

Ma, Y. \& Clayton, R., 2016. Structure of the Los Angeles Basin from ambient noise and receiver functions, Geophys. J. Int, 206:1645-1651. doi:10.1093/gji/ggw236.

Nakata, N., Chang, J., Lawrence, J. \& Boue, P., 2015. Body wave extraction and tomography at Long Beach, California, with ambient noise interferometry, Journal of Geophysical Research: Solid Earth, 120:1159-1173. doi:10.1002/2015JB011870.

Nicholson, C., Sorlien, C., Atwater, T., Crowell, J. \& Luyendyk, B., 1994. Microplate capture, rotation of the western Transverse Ranges, and initiation of the San Andreas transform as a low-angle fault system, Geology, 22, 491-495.

Nazareth, J. \& Clayton, R., 2003, Crustal structure of the BorderlandContinent transition zone of southern California adjacent to Los Angeles, J. geophys. Res., 108(B8), 2404, doi:10.1029/2001JB000223.

Richards-Dinger, K. \& Shearer, P., 1997. stimating crustal thickness in southern California by stacking PmP arrivals. J. geophys. Res., 102, 1521115224, doi:10.1029/97JB00883.

Ruigrok, E. \& Wapenaar, K., 2012. Global-phase seismic interferometry unveils P-wave reflectivity below the Himalayas and Tibet, Geophys. Res. Lett., 39, L11303, doi:10.1029/2012GL051672.

Saleeby, J., 2003. Segmentation of the Laramide Slab-evidence from the southern Sierra-Nevada region, Bull. geol. Soc. Am., 115, P665-668.

Schmandt, B. \& Clayton, R., 2013. Analysis of teleseismic P waves with a 5200-station array in Long Beach, California: evidence for an abrupt boundary to Inner Borderland rifting, J. geophys. Res., 118, 1-19.

Shaw, J. et al., 2015. Unified structural representation of the southern California crust and upper mantle, Earth Plenet. Sci. Lett., 415, 1-15.
Tanner, W., 1956. Trignometric solution from apparent dip, Trans. Am. geophys. Un., 23, 2. doi:10.1029/TR037i006p00779.

ten Brink, U., Zhang, J., Brocher, T., Okaya, D., Klitgord, K. \& Fuis, G., 2000, Geophysical evidence for the evolution of the California Inner Borderland as a metamorphic core complex, J. geophys. Res., 105, 5835-5857.

Wenzel, F., Sandmeier, K-J. \& Walde, W., 1987. Properties of the lower crust from modeling refraction and reflection data, J. geophys. Res., 92(B11), $11575-11583$.

Wolfe, D., Shaw, J., Plesch, A., Ponti, D., Dolan, J. \& Legg, M., 2019. The Wilmington Bling-Thrust: an active concealed earthquake source beneath Los Angeles, California, Bull. seism. Soc. Am., Early Ed., doi:10.1785/0120180355.

Wright, T., 1991. Structural geology and tectonics evolution of the Los Angeles Basin, California, in Biddle, K.T., ed. Active Margin Basins, Mem. Am. Assoc. Pet. Geol., Vol. 52, pp. 35-134.

Wrona, T., Magee, C., Fossen, H., Gawthrope, R., Bell, R., Jackson, C. \& Faleide, J., 2019. 3-D seismic images of an extensive igneous sill in the lower crust, Geology, 47, 729-733.

Zhou, H-W., Li, L., Bjorklund, T. \& Thornton, M., 2010, A comparative analysis of deformable layer tomography and cell tomography along the LARSE lines in southern California. Geophys. J. Int., 180(3), 1200-1222.

\section{SUPPORTING INFORMATION}

Supplementary data are available at $G J I$ online.

Please note: Oxford University Press is not responsible for the content or functionality of any supporting materials supplied by the authors. Any queries (other than missing material) should be directed to the corresponding author for the paper. 